\title{
Bessie Head in 3D: Race, Class, Gender
}

\author{
Nidhal Chami \\ University of Oran 2, Mohamed Benahmed
}

\begin{abstract}
Revisiting Bessie Head, an emblematic figure of South African literature, is a necessary step towards the recognition of African women's writings in the world literary map. Putting under focus central issues of postcolonial literature, such as the question of identity, otherness, power and gender, this author proved to be much ahead of her time and is considered by critics as a writer of the $20^{\text {th }} \mathrm{C}$ “ marching in the $21^{\text {st }} \mathrm{C}^{\text {". }}$. In her auto fiction, A Question of Power, she defines herself as an "out and out outsider", thus expressing a feeling and a state of exclusion, alienation, negation and otherness in a South Africa under the Apartheid regime but also in a Botswana where she sought refuge. This article aims at re-introducing an author who succeeded in transcending the dimensions of race, class and gender - through which she will be portrayed- to finally proclaim her Universality.
\end{abstract}

Keywords: South Africa, women writing, race, class, gender

DOI: $10.7176 /$ JLLL/67-03

Publication date: April $30^{\text {th }} 2020$

\section{Introduction}

Alone, apart, alien, apolitical, autonomous, Bessie Head is a writer whose originality deserves to be probed and whose literary production contributes, more than ever, in reopening the question "What is Women's Writing?", specifically in Africa. Born in South Africa, Bessie Head was one of the first generation of non-white writers without yet 'belonging' to it, the notion of 'belonging' bearing many nuances when portraying this author. The terrible void she felt around and within her goes back to the earliest hours of her life when she was denied existence and the claim for any filial connection, simply because she was born of a mixed marriage in a country where black and white relationship was considered as a sin. Growing in a climate of hostility and violence, in a milieu she could not cope with and with a permanent feeling of instability and loss, Bessie Head wrote her life revealing her struggle against multiple facets of racism: first, in South Africa where Apartheid relegated her to a 'Coloured' status; second, in Botswana where she lived as a refugee (a second class status) and where she faced tribalism in its cruelest and meanest forms being herself a Masarwa; third, as a woman, who suffered from sexism in both South Africa and Botswana. Hence, Bessie Head experienced racial, class and gender discrimination, for she was not enough white in South Africa, nor was she completely black in Botswana; in addition, she was a woman. This triple status 'acquired' through traumatic experiences was the cause of her vulnerability and feeling of insecurity which almost drove her to madness. In her autobiographical novels, the themes of racialism, tribalism, madness, exile and power are persistent and sometimes very disturbing especially in A Question of Power (1974), a very complex piece of literature that can be regarded as a spiritual arena where all forces and representations of power, both evil and good, contend. Attractive and provocative, the title of this auto fiction invites the reader to question power with the preconceived -though justified- idea that in South Africa, it is primarily symbolized by the whites. This article focuses on this book which surprisingly offers new interpretations of power, depicts a new setting, and creates a rather singular atmosphere that distinguishes Bessie Head's writings from her contemporaries' and even from later writers' in South Africa. Thus, an attempt will be made to portray Bessie Head in $3 \mathrm{D}$, the three dimensions being those of race, class and gender. It will also be interesting to see through the eyes of this author, a South Africa told by a woman and, beyond the boundaries she crossed, an Africa-Botswana- that adopted her only after she died.

\section{Race : In South Africa: How can I be when I am not?}

In her everlasting quest of identity, Bessie Head must have frequently asked the above question. Each time she tried to think of her origins, she never could really remember, dig in her memory and search, nor could she recollect, nostalgically or otherwise, spans of her life that she would reconstruct, re-arrange, re-visit and question as her compatriots, Es'kia Mphahlele and Peter Abrahams, for example did. Bessie Head's life was shattered in pieces so difficult to join that the puzzle remained a puzzle not only for her but also for a number of friends, biographers and critics who attempted to unveil her personality and life. It was not amnesia, nor was it a refusal to embrace the past that prevented this author to do it. For she did return to her childhood only to find a story restricted to what was reported to her; a brief story that would mark her life with heavy stigma. In $A$ Woman Alone, she introduces herself as a person without "a single relative on earth ....no family tree to refer to ...no links with heredity...no frame of reference to anything beyond myself". $(1990,3)$

Bessie Head reveals herself as a person utterly alone, deprived of any blood link, of any reference or 
identity, uprooted - the tree being a symbol of roots- not because she chose it, nor because it was her temperament, but because the circumstances -destiny?- wanted it that way: "I was born on July 6, 1937, in the Pietermaritzburg mental hospital. The reason for my peculiar birthplace was that my mother was white and my father black". (Ibid) Much more than a short account of who she is, this statement is a testimony of the self and of all that severed this self from others, inhumanely producing her as the 'other'. From the very moment she was born, she had no right to 'be', a case of alienation and exclusion sustained by the Apartheid system. Among the reasons why non-white South Africans, namely coloureds, could not 'be', were the laws and acts that prohibited what is nowadays known as 'mixed', 'interracial', 'interethnic' or 'cross-cultural' marriage. These terms have recently replaced the offensive concept of 'miscegenation'(Note1) which was used for a long time in South Africa and which referred to the mixing of 'kind' or 'type' of people. With its negative connotations, this concept provoked the reaction of many writers like Lewis Nkosi who explains in his collection of essays, Home and Exile, how he first discovered his Africanness and what it meant to be non-white :

I first discovered my Africanness not, as one might imagine, when I discovered I was black. I took my colour quite for granted. I discovered my Africanness the day I learned that I was not only black but NON-white.

......From that day onwards, I began to regard this prefix, NON, with

Absolute hostility. Everywhere I went in public places, notices shouted at me: "NON-Whites Only" and every time I read the message, it vividly brought to mind the crude fact that in the eyes of the world my life represented something negative, something NON !(1986, 31-32)

As for Bessie Head, she goes even further in stressing the absurdity of categorizing people according to the colour of their skin, ironically telling not only about the white vs black dichotomy, but also about the "colour overtones' that distinguished the inhabitants of the Cape: "Here were people with different shades of brown. Those who looked white, those who looked brown, those who looked like Indians, and those who looked like blacks." (in Abrahams, 1986, 4).

It is, in fact, this feeling of 'looking like' without exactly filling the criteria of resemblance, this 'not-reallywhite' and 'not-really-black' position, this liminality, which was at the heart of the tragedy of Bessie Head. As seen by a number of South African writers, the theme of miscegenation is a biological and national tragedy. However, in spite of its significance, it did not hold the place it required in South African writings. Only three authors used it as a central theme in their novels: Sarah Gertrude Millin's God's Stepchildren (1924), Alan Paton's Too Late the Phalarope (1954), and Lewis Nkosi's Mating Birds (1987). Published twenty and thirty years apart, they induce the question: why did South African writers overlook or ignore this issue in spite of its gravity? Is it because the main concerns of South African writers were primarily to depict their people's daily life: poverty, violence, injustice, discrimination or was it a taboo question for both whites and blacks, knowing that such relationships were those of rapist to raped, which, for both criminal and victim, was hard to confess?

Although Bessie Head was born of a consensual relationship, the latter was forbidden by a series of laws implemented to proscribe mixed marriages, which had disastrous psychological effects on the coloureds not only because of discrimination but also because of the sense of immorality they entailed. In 1949, the Prohibition of Mixed Marriages Act, outlawed marriages between people of different races. It was followed by the Immorality Act (1950) which forbade sexual relations between whites and non-whites, inferring that any infant conceived of this relation would be deemed 'illegal'. Even more tragic for the victim of this union was its interpretation by the authorities as a crime and a betrayal of the white race. In A Question of Power, Elizabeth, the main character of the story, just like Bessie Head, suffers from an illegitimate birth, a trouble she has to face all along her life. As Hershini Bhana explains in her article, "Reading Ghostly Desire: Writing the Edges Of Bessie Head's A Question of Power", "Elizabeth's (white) mother has betrayed the metonymic signifier of the nation-state, the raced biological family, with sexual acts that were illegal in South Africa"; as a result, "... Elizabeth's existence is impossible both in terms of her parents coupling and in terms of her being born at all."(in Ibrahim, 2004, 40). In fact, Bessie Head's mother, who came from a white upper-class family, was admitted to the Pietermaritzburg mental asylum when she was discovered to be pregnant by their stable boy. Six years later, she committed suicide. Bessie Head never met her mother nor her father. In A Question of Power, Elizabeth reports the situation as it was told to her by her foster-mother: "First they received you from the mental hospital and sent you to a nursing-home. A day later you were returned because you did not look white. They sent you to a Boer family. A week later you were returned. The women on the committee said: "what can we do with this child? Its mother is white."(17)

Rejected because she was a mulatto, was the crime she had to pay for even among children at school. Elizabeth returns to those days, perhaps the only memories of her childhood, when she was forced into isolation, locked by the principal because she had defended herself against other children who could scratch and bite one another without being punished while she represented a threat because of her 'probable insanity'. She was sporadically "isolated from the other children" (ibid, 16) for a week or less, hence, experimenting seclusion and 
isolation in the very place where she received education. She learnt a lot from the books she read: books that taught her western thoughts, ideas and ideals, books that sublimated religion, others that advocated equality, but as she implies, none of these really offered an answer to her central question which was: why, in South Africa, the whites "were just born that way, hating people, and a black man or woman was just born to be hated" (1990, xi). Nor could she approve of the fact that in this same country, the blacks were not considered as human beings with their own personalities or individualities, but as she said, "they were races, not people" (1974, 44).

\title{
3. Class : In Botswana: "I am an Out and Out outsider"
}

Unlike the majority of non-white South Africans, Bessie Head chose a bordering country as a refuge explaining her choice as follows:

\begin{abstract}
In my eyes Botswana is the most unique and distinguished country in the whole of Africa. It has a past history that is unequalled anywhere in Africa. It is a land that was never conquered or dominated by foreign powers and so a bit of ancient Africa, in all its quiet and unassertive grandeur, has remained intact there. It became my home in 1964.
\end{abstract}

$(1990,12)$

Nevertheless, she was soon disillusioned by this 'home' that proved to be inhospitable to her. In fact, she bore the status of a refugee for a long time and had to report at the police camp for thirteen years before she was at last accepted as a Botswana citizen. Bessie Head had responded to a call for teachers, hoping to find in Botswana the freedom she was deprived of in South Africa. However, as her numerous letters attest, she was struck by the totally new environment she had to adapt to. She suffered enormously from the villagers' hostility and lived with the certainty that she was going to be killed in "this quiet-seeming village", where she says "nothing ever happens" and where "there are only people and animals and starvation, fear, frustration and dogeat-dog" $(1991,9)$.

It would be interesting at this point to refer back to Bessie Head's decision to settle in an African country while she could go to Europe or to the United States of America. What is strange in her attitude, though, is her demarcation from her contemporary writers in expressing her attachment to Africa. While Es'kia Mphahlele and Chinua Achebe undertake the task of restoring the image of Africa through what is called "Ubuntu" - which means African Humanism- and "the fundamental theme" claiming an African philosophy of great depth and value and beauty .... poetry and above all...dignity" (Achebe, 8), Bessie Head advocates Universalism. Compared with black and coloured South Africans' novels like Alex La Guma's $A$ Walk in the Night, Es'kia Mpahalele's Down Second Avenue or Richard Rive's Emergency, the reader will first note the difference in the setting. For instance, La Guma's $A$ Walk in the Night plunges the reader in an urban area, deep in the ghetto, in the slums' life, with its strong smells and sounds, its dirt, its violence in District Six, a famous coloured ghetto in Cape Town where Bessie Head herself lived for a while whereas Bessie Head's novels lead to rural areas and villages, where life, though harsh, is so quiet. The 'state of emergency', the particularly brutal atmosphere so well-known to South Africa does not come into view in her novels. No police raids, curfew tension, whistles, sirens, boots' beat as movements and sounds that are forcefully integrated in the South African setting occur in her major works. As for characters, namely the whites, they are not described as antipathetic or antagonistic while in Alex La Guma's, "they had hard, frozen faces as if carved out of pink ice, and hard dispassionate eyes, hard and bright as pieces of blue glass" $(1988,11)$. This description of the white policemen sets a climate of hostility and fear as well as a feeling of diffidence in front of 'the law'. Such an unbearable and revolting atmosphere is not visible in Bessie Head's works; so invisible in fact, that one may almost suspect a sort of disengagement from a cause powerfully defended by black and coloured writers.

Revealing this aspect of Bessie Head's narratives is by no means an intent to misjudge or criticize a writer who experienced racialism in its cruelest forms. The aim is rather to introduce a woman who had the courage of her convictions and who dared defy an established 'order' be it white or black. Her 'lack of commitment', if one may say so, can be explained by her apolitical position, which she proclaimed after being disillusioned with politics and politicians. What should be recalled, however, is that she was an African nationalist and a supporter of the Pan-Africanist Congress (PAC) led by Robert Mangaliso Sobukwe whom she trusted and considered as a hero. Bessie Head also worked as a journalist for Golden City Post and soon became part of a large circle of political activists and writers. She was known for being once a "fire-eating Africanist", who raged at whoever offended her views, as is reported in Randolph Vigne's A Gesture of Belonging (1991,1). She had also significantly contributed to the seminal periodical, The New African. The latter gathered other famous South African writers like Matshikisa, Themba, Mphahlele, Nkosi, all of whom formed the Drum School, one of the most widely read magazine in Africa considered as part of black South African's daily life. Once again, Bessie Head who worked with them marked her difference not only in style but also in her apolitical approach. 
Nonetheless, if she happened to follow the movement in the very beginning, she later regretted it and explained that "the South African environment completely defeated her as a writer (1990, xv). Published in The New African, the following poem, which is the only one she wrote, reveals a radical change from all that she produced later:

\author{
I am Black \\ Okay? \\ Hot sun and the geographical set-up \\ Made me Black; \\ And through my skin \\ A lot of things happen to me \\ THAT I DON'T LIKE \\ And I wake each morning \\ Red murder in my eyes \\ 'Cause some crook's robbed me again, \\ Taken what little I had right out of my hands \\ With the whole world standing by \\ And doing nothing... \\ Okay? $(1962,10)$
}

The fury expressed in this poem, the reproach made to the world, and the "I am Black" identity she shows off and reclaims, does not occur with such a vigor and threatening tone, in her later works. She seems to have lost faith in any political commitment after most of her colleagues were dispersed and exiled. In fact, 1961-62-63 were very hard times in South Africa. The Sharpeville Massacre followed by a state of emergency, police repression, harassment and arrests, forced political action into underground armed resistance, but the majority of activists were jailed while the others fled. Shattered and demobilized, their actions weakened and the situation became quite desperate especially for writers like Bessie Head who had also planned to leave South Africa. The latter's disappointment with politics is disclosed in her novels When Rain Clouds Gather and Maru .Criticizing the dishonest practices of authorities and tribal chiefs in Botswana, she evoked with bitterness certain South African political parties which considered themselves as the vanguard of African nationalism while they turned to disappoint the people who trusted them. According to her, " to many, Pan-Africanism was almost a sacred dream, but like all dreams it also has its nightmare side.....If they have any power at all, it is the power to plunge the African continent into an era of chaos and bloody murder"(1974,47). More vehemently, she accused these same politicians "who [swept] the crowd away by weeping and wailing about the past" then "[stole] and [cheated] people once they [got] into government" (133). She came to hate "labels like Black Power or any other rubbish of that kind"(ibid) because her main interest lied in a greater and larger foundation which was universal. Head's cause transcended the continent, the race, the tribe: it is not an African Humanism that she displayed, but simply Humanism that she believed in and claimed: "I've got my concentration elsewhere', Elizabeth says, "It's on mankind in general, and black people fit in there not as special freaks and oddities outside the scheme of things..."(ibid).

Is it because she was not totally Black that Head had the ability to think beyond colour, or is it a certain 'maturity' attained in spite and because of oppression? Is it an excess of goodness very few people living in desolation would understand and accept? Ignoring these questions, would mean hiding very important features of Bessie Head's personality which she herself unveiled not only in her autobiographical works but also in the numerous letters she wrote to her friends. Ironically, while she lived her hybridity most often as a handicap, she found in it the key to intellectually and spiritually penetrate both worlds. She could analyze in a more objective way the madness, the meanness but also the grandeur of mankind which she always asserted to be her identity. In A Question of Power, she announces it through a significant statement made by Sello, the protagonist representing the good side of human soul. The book opens with the following description of this character, the first line astonishingly appealing the reader:

It seemed almost incidental that he was African.

So vast had his inner perceptions grown over the years that he preferred an identification with Mankind to an identification with a particular environment. And yet as an African, he seemed to have made one of the most perfect statements:

"I am just anyone". (11)

As pointed out earlier, Bessie Head seems to have acquired through years a certain ripeness that allowed her to surpass her immediate conflicts without yet suppressing them. She seized the world differently, with a new vision, which outdistanced her from politics, for she no longer trusted any kind of commitment except that to Mankind with all its shades and hues. 
Before attaining the capacity to transcend the problem of race, Bessie Head was to experience it in Botswana too. She realized that race, class and gender discrimination was not limited to South Africa. As an illustration of this painful and frustrating state of facts, she shows in A Question of Power, how Elizabeth lives her hybridity. The latter's nervous collapses come from her incapacity to cope with the worlds she was forced into. It is a question of power - the others'- or lack of power - hers- that is echoed all along the story. Who have the power and how do they use it? The tension expressed in the following passage is accompanied with a feeling of impotence and fear that pervades the whole novel. Elizabeth is subjected to a permanent psychological threat and assault, being constantly reminded that she is a hybrid or a mulatto, in other words, not a 'pure' black:

There was a pressure turned on her, so powerful

Elizabeth collapsed flat on her back. She just

lay there nearly choked to death. It was like

a wild, insistent chant in her ears: 'Die, die,

die'. But a current was turned on, choking her.

......She fell into a deep, exhausted sleep,

only to awaken the following morning to a greater

terror still. Someone had turned on a record

inside her head.....'Dog, Filth, the Africans will

eat you to death." (45)

In most of her works, Bessie Head raises the question of racial discrimination against ethnic minorities, like the Basarwa in Botswana. Maru, for instance, is another illustration of this type of discrimination which dryly recalls some details of the Apartheid system. She identifies with this minority because she is coloured and is unmistakably reminded of her lack of 'purity' in Botswana. Bessie Head could understand that in South Africa there was no escape from a rigid classification of races, but she could not admit it in Botswana. Another demonstration of power through racial discrimination was then displayed in this country where people were also categorized and relegated to a lower social status on a racial basis. Bessie Head undergoes both internal and external pressures which she cumulates and tells about in her work either through open statements, reflections or dreams. They all build up to a climax which justifies her later nervous collapse. One of the pressures that is insisted on is tribalism; how she lived it, how she resisted to it and how she fought against it. In her writings for instance, the white/black dichotomy which prevails in both white and coloured South African fiction, shifts to a black-on-black discrimination. Thus, while the author introduces an important theme which is tribalism and which she considers as the major defect in a society, one which chokes its members and hampers progress, she also unveils a repressed part of her identity and recounts her double exile. In a letter from Serowe, she describes a tribal society as one which "..hasn't a flexibleness to allow for a flow of ideas, activity. People on the whole are quite, quite flat and only here and there you'll get a spark. Thought is en masse and you struggle to pick out SOMETHING in the blur.( in Vigne, 27).

It is in this very confined, stagnating atmosphere that Bessie Head had to live for many years. The idea that she was an "out and out outsider" $(1974,26)$ was hence reinforced in Botswana where she was rejected not only because of her origins but also because of her being a woman. Throughout her novels, she repeatedly draws attention to the Batswana's violent prejudices which dramatically echo those of the white South Africans. Again, she recalls examples of racism likely to be recognized in South Africa. For example, in Maru, Margaret the school teacher who belongs to the Masarwa - the lowest social cast in Botswana- is not accepted because it is firmly believed that the San are racially inferior. Continually referring to harassment, Bessie Head told about her experience as one of the most bitter, the most cruel and the most lonely one could ever live. Approaching the question of gender through the incidents she lived, she let us see how much more devastating gender discrimination is when combined with race and class.

\section{Gender}

An atypical woman is a woman who is uncommon, not ordinary, exceptional and different. Bessie Head was such a woman even if she regarded herself as just everyone; in a sense, she was an 'other', a woman apart, and as such, could not be defined as a feminist. One is tempted to consider her as an 'other' distinguished from the feminist 'others' or that she was an 'other- and- other other', to echo her own identification as an 'out-and-out outsider', partly alienating her from her female mates. In reality, this author was very attentive to women's hardships, but although she paid tribute to black womanhood, namely in The Collector of Treasures, she denied the necessity to be a feminist to voice women's cause, remarking:

I am not a feminist.... in the sense that I do not

view women in isolation from men....I view my

own activity as a writer as a kind of participation

in the thought of the whole world.... Writing is not

a male/ female occupation...I do not have to be a 
feminist. The world of the intellect is impersonal, sexless. ( in Eilerson, 238)

Indeed, ranging Bessie Head within feminism would reduce the universal scope she constantly proclaimed. It would mean identifying her with a group, a branch of society, a 'minority', the thing which she completely refuted. According to her, voicing women does not need adherence to a group, a party or an assembly. Ama Ata Aidoo, an icon of African literature who was also labeled feminist, claimed that "simply writing about women [does] not make us 'feminist writers' (in Ibrahim, 196).

Actually, it has become an almost natural and spontaneous attitude to think of women's writings as inevitably dealing with feminism. Critics seem more tempted to seek defensive or offensive reactions on the part of women writers rather than find messages, reflections and thoughts that transcend the problem of gender. That women experienced and are still undergoing all forms of oppression and repression is a fact which cannot be denied and which requires and imposes revision, recognition and correction. However, to confine women's artistic potential within a feminist framework gives the impression of choking their voices and talents. Considering women's production mainly as 'feministic commitment' may prevent the reader from appreciating it as a work of art and, consequently, could be prejudicial to its authors. On the other hand, there is a need for commitment if women writers want to change mentalities, and this can mainly and effectively be operated through writing that Hélène Cixous defines in "The Laugh of the Medusa" as "precisely the very possibility of change, the space that can serve as a springboard for subversive thought, the precursory movement of a transformation of social and cultural structures". (875-93)

In South Africa, women had to wait long before this subversive thought emerged. The transformation of cultural and social structures demanded a revolution (not yet achieved) especially in a society where the assumption of male authority over women was reinforced by both the African traditional structure and Afrikaners' hegemonic system. More than other African women's struggle, the South Africans' in particular has to be acknowledged, for these women were subjected to both racial and gender oppression. They were discriminated against as blacks and as women. The many forms of dispossession and injustice, the abuses of power, the racially oppressive system of Apartheid with its heavy impact on women were subjects that were not noticeable until the 1990's with the emergence of a whole new generation of women voices who argued that gender and racial oppression had to be contested simultaneously.Writers like Ellen Kuzwayo, Miriam Tlali, Zoe Wicomb, Nadine Gordimer, Doris Lessing have all testified to the most unjust and humiliating system ever established in a society. Their novels and autobiographies question what was unquestioned before, combining political issues with literary insight.

As for Bessie Head, though not a feminist, she expressed in her own manner the complex interweaving of racial and gender oppression. She had access to the world of power and to history precisely by the act of writing. In A Question of Power, the text that she writes and that writes her, she reveals men's greed and vanity in the person of Dan. This character is the epitome of power in its most awful manifestations. He is the embodiment of evil and malice, the rapist and the pervert, the attractive man who uses his charm to deceive women and abuse them, the one who obtains all he wants because he is powerful. Dan is also the man who wants to control Elizabeth's life and who uses both seduction and violence to achieve his aims. It is not a coincidence that Bessie Head indicates a date, 1910, as being the year when he gained "directorship of the universe"( 25). In the history of South Africa, this is the year when the Act of Union marked the official birth of the white South Africa, and when Cecil Rhodes declared that "the key to the real question of South Africa is the supremacy of the white race."(in Lefort, 30). The date 1910 is historical for its implications of the purity of race. To what extent is this relevant to Dan and why has Bessie Head made this analogy with him? This can be explained by the writer's allusion to racism when it is reversed, and how malevolent and harmful it is whether expressed by whites or by blacks. It is also an illustration of power be it white or black, which sends us back to Elizabeth's struggle as a mulatto in Botswana and to the record she felt someone had turned inside her head. It went on and on telling her she was a "dog, filth, the Africans will eat [you] to death."( 45) It was Dan who obsessively reminded her of the 'impurity' of her hybrid body. Making her feel ugly and inferior because of the dilution of her blackness, he introduced a girl who had her hair done in the traditional style: "I like girls like this with that kind of hair. Your hair is not properly African" (127). Hybridity, the record went on, is a contaminating disease, like leprosy. Medusa, who is Dan's ally, also threatened her saying that "Africa [is] troubled waters" and that "[you]will only drown here. You're not linked up to the people. You don't know any African languages."(44) The same cruelty and discrimination she had known in South Africa is reproduced in Botswana. The power to harm and break the nerves was the art of Dan.

Certainly, the personality of Dan is not representative of men, but this character, reappearing in Bessie Head's other novels like Maru, suggests that he was not a unique sample of male abuse and 'power'. Different from A Question of Power for being often qualified as a fairy tale, Maru as well abounds with symbols. The symbol of power for instance, is incarnated by two men who are almost replicas of Sello and Dan. The notion of good and evil is again the focus of the story, and the central character, Margaret, just like Elizabeth is split in two, 
swinging between two male forces, undergoing them, but finally liberating herself from both.

The structure of $A$ Question of Power also offers a significant illustration of male power. It is divided in two chapters, the first bearing the title, Sello, the second, Dan, which can be interpreted as good versus evil, life versus death, light versus darkness, day versus night. While giving the impression to introduce a sort of duel between the two men, this dual structure rather constitutes a wholeness produced by two selves. In other words, Elizabeth's quest reveals through the two males (ghosts) who visit and at times inhabit her, either a depiction of her own self being torn between good and evil, or a hidden complicity of two apparently different men plotting against her. From the beginning she 'accepts' to be accompanied by these two men in her journey into the self: "The three of them had shared the strange journey into hell and kept close emotional tabs on each other. There seemed to be a mutual agreement in the beginning that an examination of inner hells was meant to end all hells forever."(12) Each one knew there was an inner hell to be examined. Each one needed an exorcism to be operated. The question that remains is why has Head chosen male characters/ghosts to undertake this journey? It can be assumed that in this society where both men and women were repressed, the latter were those who endured discrimination most. For in this journey, it is Elizabeth who is the object of subjugation, "The pivot of the examination was Elizabeth. Both men flung unpleasant details at her in sustained ferocity."(ibid) Margaret Tucker offers another explanation of Bessie Head's accompaniment by two men in her mental journey. According to her, as a "receiver of horrors", Elizabeth has been the text for Sello's and Dan's hells. "In order to examine her own hell, she must find a text to inscribe it so that she can see rather than be consumed by herself as Other." (170-181). Once again, the text imposes itself as the most effective resort for women to liberate themselves from oppression, to shift from a passive subject to an active one and transform silences into voices.

\section{Conclusion}

A Question of Power is pregnant with expressions and symbols of power, including men's and Gods'. It is also a text that requires some sort of power to be read and understood. Is it because it is written by a woman that it presents so many overtones? In other words, is it a feminine feature to leave one's books open to debate and reflection, some would say to uneasiness? For if the reader recognizes in Bessie Head's story a final message of love, a lot of other questions remain still unanswered. Cixious writes: "A feminine textual body is recognized by the fact that it is always endless, without ending: there is no closure, it does not stop, and it is this that very often makes the feminine text difficult to read" $(1989,53)$. Some other feminist critics emphasize Cixious's argument and think that, in general, male writers seem more interested in closure while female writers respond with openendings; they also assume that "feminine logic in writing is associational, male logic-sequential-goal oriented" and that "male objectivity is challenged by female subjectivity."(Guerin et al, 1999,201). Linearity is furthermore stressed as being almost absent from women's writings. These characteristics seem to fit Head's auto fiction which is complex, open-ended, made of flash-backs, in-and-out passages from dream to reality, madness to awareness. Not feminist but feminine, Bessie Head shares with women textuality and one essential thing which is : motherhood. Perhaps is it feminism's political biases that made her stand aloof. Nevertheless, feminists are the ones who argued that it is the possession of power that determines who is oppressed, another way of saying: It is 'a question of male power.' To this submerging power equated with evil and darkness, Bessie Head opposed goodness and light extorted from the very hell she experienced as a non-white in South Africa, as a refugee in Botswana and as a woman in a patriarchal society. In a sense, her utopian vision was a triumph over many forms of power since she finally succeeded in 'belonging' not only in the universe that she wanted to be her home but also in the three dimensions of time that she marked with her seal. For she is a woman of the past, of the present and, doubtless, of the future.

\section{References}

Abrahams, Cecil. (1990). The tragic life. Bessie Head and literature in South Africa. New Jersey: Africa World Press.

Bhana, Hershini. (2004). 'Reading ghostly desire: Writing the edges Of Bessie Head's A Question of Power'.In Ibrahim,Huma,ed., Emerging perspectives on Bessie Head, 33-50. Trenton \& Asmara: Africa World Press.

Cixous, Hélène.(1976). The laugh of the Medusa. Signs:Journal of Women in Culture and Society, Vol.1.N 4 , 875-893.

--- (1989). Castration or Decapitation. Signs: Journal of Women in Culture and Society, Vol 7,N 1, 41-55.

Eilerson, G.S. (1995). Bessie Head : Thunder behind her ears. Portsmouth, N.H :Heinemann.

Guerin, W. L. Labor, E. Morgan, L. Reesman, J.C. Willingham, J.R. (1999). A handbook of critical approaches to literature. New York: Oxford University Press

Head, Bessie. (1962). “Things I don't like”. The New African.July, p.10.

--- (1968). When rain clouds gather. London : Heinemann.

--- (1971). Maru. London : Heinemann,.Print.

--- (1974). A question of power. London: Heinemann. 
--- (1977). The collector of treasures. London: Heinemann.

--- (1990). A woman alone. London: Heinemann.

Ibrahim, Huma. (1996). Bessie Head, subversive identities in exile. USA: The University Press of Virginia. ---. (2004) Emerging perspectives on Bessie Head, Trenton \& Asmara: Africa World Press.

La Guma, Alex. (1988). A walk in the night. G.B: African Writer's Series.

Lefort, René. (1977). L'Afrique du Sud. Histoire d'une crise. Paris : Maspero.

Mphahlele, Es'kia.( 1971). Down Second Avenue. London: Faber \& Faber.

Nkosi, Lewis. (1986). Mating birds. London: Constable.

---. (1983). Home and exile. London \& New York: Longman.

Paton, Alan. (1981). Too late the phalarope .London: Scribner Paperback Fiction.

Rive, Rive. (1964). Emergency. London : Faber \& Faber.

Tucker, Margaret.E. (1988). A 'Nice-Time Girl' strikes back: an essay on Bessie Head's A Question of Power. Research in African Literatures, 19.2,170-131.

Vigne, Randolph.(ed.) (1991). A gesture of belonging. London: Heinemann Educational Books. 